Article

\title{
Danube Cruise Tourism as a Niche Product-An Overview of the Current Supply and Potential
}

\author{
Melinda Jászberényi and Márk Miskolczi * \\ Corvinus University of Budapest, Institute of Marketing, Fővám tér 8, H-1093 Budapest, Hungary; \\ jaszberenyi@uni-corvinus.hu \\ * Correspondence: mark.miskolczi@uni-corvinus.hu
}

Received: 24 April 2020; Accepted: 1 June 2020; Published: 4 June 2020

\begin{abstract}
Tourism in the 21st century is being re-shaped by constant changes in consumer trends. The Danube, Europe's second-longest river, has rich potential for tourism over its whole course, and river cruises offer superb opportunities to explore. This study aims to provide a comprehensive picture of the most important characteristics of cruise tourism on the Danube. In our research, a literature review (LR) and content analysis (CA) were used to examine trends in the inland waterway cruise sector, which, despite the growing interest in the product, is still not deemed to be a part of mass tourism. Danube cruise tourism relies heavily on alternative (niche) tourism features, which satisfy both cultural and authentic tourism preferences. Currently, many elements of niche tourism are missing from the product supply, but, with a modest addition of such features, the demand for the product could increase and its economic performance in the period following the expected recession would be enhanced.
\end{abstract}

Keywords: river cruise tourism; Danube; niche tourism; cultural tourism; heritage

\section{Introduction}

Tourism became a driving force for the movement of people in the 21st century. In addition to the common manifestations of the industry, several emerging trends (e.g., seeking for authenticity, digital revolution of services) are contributing to tourism being one of the engines of economic improvement worldwide. At the same time, the sector also faces several difficulties (e.g., the environmental impact of aviation, overtourism, or the current pandemic situation). Mitigating the latter could be a major challenge for the future. Cruise tourism is one of the strongest components of the sector, the economic impact of which is remarkable; the total worldwide market is worth USD 138 billion [1]. It is, however, important to stress that the outstanding economic performance is not only generated by ocean-going cruise ships. Inland waterway or river-cruising - especially on the Danube-is among the fastest developing sub-areas of leisure travel; it can mix or combine elements in its offers, creating alternative, marginal—but nonetheless superb—attractions to satisfy unique tourist demands [1]. During the intensive operation period (March-October), river cruises on the Danube contribute at least EUR 110.7 million to the regional economy [2] (such destinations as Regensburg, Passau, Linz, Vienna, and Budapest). However, despite the positive trends, Danube cruise tourism is less important in scientific research. Scholars primarily concentrate on ocean-going cruises [3,4] and its impact on the ecosystem [5,6]. Key issues (e.g., the individual, theoretical categorisation of river cruise tourism, the examination of development opportunities to ensure the long-term economic sustainability of Danube cruise tourism) are mainly overlooked. It is important to stress that Danube cruises are in many ways similar to ocean cruises [4] but cannot be categorised as mass tourism. The target group and product portfolio are significantly different, and so analysing the characteristics of the industry should be an important task for tourism research. Therefore, the aim of this study is to provide a 
comprehensive analysis of Danube cruise tourism along with four factors: the identification of the main players (1), the targeting of key potential markets and their demands (2); showing the dominant niche elements involved in current itineraries (3); and, with these in mind, formulating product development proposals (4). For these purposes, we used a literature review (LR) and content analysis (CA).

The academic relevance of our study is that it contributes to a more precise typology of Danube cruise tourism, which is a special hybrid of cultural, rural, and urban niche elements. Our results point to the dominance of the cultural macro-niche in Danube cruise packages, as well as the potential risks (e.g., a lack of product diversity) and development opportunities (e.g., targeting new segments) of the industry. As overtourism is an increasing problem in European destinations, it is clear that the development of every tourism product must follow a sustainable path, i.e., by taking into account the capacity of the destinations and also the satisfaction of consumers. Our development proposals based on niche tourism follow these principles-which is a novel approach in the analysis of Danube cruise tourism.

The article is structured as follows: river (Danube) cruise voyages are a special form of tourism, and so in Section 2 the characteristics of niche tourism are shown, with its potential and limitations. This supports the transparency of the results and proposals offered by the analysis. In the third section, the research plan (the formulation of research questions (RQ) - Q1, Q2, Q3), explanation of the methods applied-LR, CA) is described in detail. The fourth section discusses the topic of Danube cruise tourism from three perspectives: it provides a comprehensive picture of the emergence and current supply of the industry (1), as well as of the key demand characteristics (2) and economic indicators (3). The results of the content analysis, i.e., our analysis of the niche elements appearing in the offers of the main cruise operators, are also presented. In addition to identification and grouping, the role of the different niche elements is also evaluated and then, based on the result, product development proposals are summarised in Section 6. Finally, our conclusions (Section 7) and the limitations of our research and ideas for future research directions (Section 8) are detailed.

\section{Current Issues and Significance of Niche Tourism}

Participants in mass tourism use a relatively large number of relatively schematic services offering almost the same experience [7]. In the 1960s and 1970s, due to the emergence of the Fordist approach, travel companies started to focus on cost-effectiveness and offered standardised packages and services [8,9]. Therefore, competition between service providers and destinations is mainly limited to price, which plays a key role in the travel decisions of mass tourists $[8,10]$.

Currently, on the demand and supply sides of tourism, the role of creativity and innovation has continuously strengthened and services have been created which are economically profitable, so meeting the criteria of economic, cultural, and ecological sustainability [11,12]. In this context, many new tourism activities are appearing on the market which are increasingly difficult to classify according to current tourism typologies. The summary name of the novel product range which meets special tourism needs is niche tourism (or alternative tourism [13], modern tourism [14]), many forms of which can be distinguished (Figure 1). The peculiarity of niche tourism is that special needs occur only among a narrow group, and so the demand for the product is not able to become mass-based-or, at best, only slowly $[15,16]$. 


\begin{tabular}{|c|c|c|c|c|}
\hline Macro niche types & \multicolumn{2}{|c|}{ TOURISM TRENDS } & & \\
\hline \multicolumn{5}{|l|}{ [ M Micro- niche typese $]$} \\
\hline & MASS TOURISM & \multicolumn{2}{|c|}{ NICHE TOURISM } & \\
\hline & $\begin{array}{c}\text { Conventional tourism market } \\
\text { where a large number of people } \\
\text { appears }\end{array}$ & \multicolumn{2}{|c|}{$\begin{array}{l}\text { Special tourism market where a } \\
\text { small mumber of people appears }\end{array}$} & \\
\hline CUltural & ENVIRONMENTAL & RURAL & URBAN & EMERGING \\
\hline Heritage tourism & Nature and wildlife & Farms & Business & Photographic \\
\hline Tribal & Ecotourism & Wine and gastronomy & Conference & Small cruises \\
\hline Religious & Adventure & Sport & Exhibition & Volunteer \\
\hline Educational & Alpine & Festival and events & Sport & Youth \\
\hline Genealogy & Geotourism & Arts and crafts & Gallery and Art & Sex \\
\hline Research & Coastal & Transhumance & Medical & Space \\
\hline
\end{tabular}

Figure 1. Tourism trends—-typology of the most relevant niche segments. Source: Authors' own editing based on [10].

In our research, we followed a niche typology [10], which allows the identification of the most important niche segments. To avoid conceptual overlap, the terms macro- and micro-niche are introduced, the former meaning alternative tourism products in the broadest sense (such as cultural or rural tourism) and the latter their narrower branches (such as religious or wine tourism) [10]. Research on niche tourism initially focused on defining the concept and exploring the basic characteristics of different niche products, but the expansion of knowledge increasingly allows for a multifaceted analysis of a particular product. Currently, there is a lack of systematic analysis of the competitiveness, success, and added value of niche products [14]. There is also a lack of exploration of international trends and into the identification of barriers to the emergence of new services in niche tourism [15].

According to the niche typology, three specific niche categories (Figure 1) and several micro-niche elements (tribal, sport, space, etc.) have been defined. As the focus of our research is broad, not all niche types are described in detail, whilst only the elements arising from Danube cruise tourism supply will be analysed. There is, in addition to the three categories, a "new wave-emerging" category, which are difficult to classify into other categories. This confirms that niche research (e.g., adapting typologies to current trends) is an increasingly important task for tourism science. As we can see, Danube cruise tourism is not specified in Novelli's niche typology. Only small cruises (with no further specification) were mentioned as new, undefined tourism products. It is clear from the tourism literature $[16,17]$ that ocean-going cruises are a superior segment of mass tourism, but the theoretical classification of river cruise tourism (especially on the Danube) is inadequate. Some typologies classify river cruises as a special type of entertainment $[17,18]$, whilst others $[7,19]$ mention cruises as 'soft' tourism activities (e.g., sightseeing). Consequently, river (Danube) cruise tourism is not part of mass tourism, but its exact classification is missing and so our study attempts to clarify the characteristics of the product.

Niche elements are often included in national tourism development strategies, as they allow for a highly sustainable form of tourism. Meeting the needs of a smaller, but generally, more willing to pay-segment can be very profitable for the destination in the long run. With the development of niche tourism, the preservation of the tourist attractions of the given destination (e.g., natural treasures, architecture) in their original state is easier to achieve and serves the sustainability of the tourism sector $[15,18]$. Despite the positive perspectives, niche tourism must be chosen carefully [11]. Researchers $[12,13,15,18]$ emphasised that the return on over-specialised products tends to be longer and risky, and the economic stability of niche products fluctuates easily. If the target group of a given micro-niche (e.g., religious) is a narrow segment (e.g., senior tourists), to avoid negative effects on them (e.g., COVID-19-situation) the lack of visits can persist after the threat has passed, so losing the niche product's ability to generate profit. Niche tourism often attracts people from a very specific 
demographic group whose sense of taste may vary too quickly for the destination to adapt $[13,18]$. The threats of niche tourism can be mitigated by embedding it in a product offering that is more stable, more predictable, and at the same time has opportunity to meet special needs. Danube cruise tourism may have this ability.

\section{Research Design}

Before embarking on the research process, our basic research question and the related sub-questions were formulated as follows:

RQ: What micro-niche elements does Danube cruise tourism embrace?

Q1: Which micro-niche element dominates the product range and why?

Q2: What other micro-niche elements could be incorporated into the offering for successful product development and to alleviate the impacts of the recession?

Q3: What kind of gaps can be identified in product development, and what additional market research directions are appropriate?

For answering the research questions, a literature review (LR) and content analysis (CA) were carried out (Table 1). Based on the results of the review process, six dominant market players (cruise companies with the most products and the highest market share) were selected. These were subjected to a content analysis process to reveal the niche elements of Danube cruise tourism (Figure 2). An LR is an exploratory research process to synthesise and critically estimate inquiries on a specific topic according to a pre-defined aspect [20]. Since existing study outcomes are gathered and incorporated, our LR should be categorised as secondary studies aiming to identify fields, which demand more attention from researchers and unify current thinking on the examined phenomena [21]. Our literature review aims to show the basic characteristics of Danube river cruise tourism and identify the most effective market players. As Figure 2 shows, our research comprises four steps, which begin with a search applying online databases (Google Scholar, Springer, T\&F online, Scopus, Science Direct, Research Gate, Web of Science) and keywords (Table 2) to show relevant manuscripts related to the characteristics of cruise tourism. The first step in the analysis was conceptualisation, in which the criteria of the research plan were defined:

- Papers must focus on the cruise industry, and especially on Danube cruise tourism, its basic characteristics and economic issues. To provide this, five keywords were run (Table 2).

- Manuscripts must cover the current research results; therefore, we prioritised papers from the last ten years, but relevant research published before 2010 was not excluded.

- Manuscripts included in the research must be peer-reviewed to ensure reliability (Table 3).

Table 1. Research objectives and processes. Source: authors' own editing.

\begin{tabular}{ccc}
\hline Research Objective & Research Method and Processes & Related RQ \\
\hline $\begin{array}{c}\text { Identification of the basic characteristics } \\
\text { of river cruise tourism, especially along } \\
\text { the Danube. }\end{array}$ & Literature review (LR) & $\begin{array}{c}\text { Preliminary analysis of the current } \\
\text { state of the tourism product to } \\
\text { identify the research objectives } \\
\text { (RQ and Sub-Qs). }\end{array}$ \\
\hline $\begin{array}{c}\text { Identification of the biggest market role } \\
\text { players to reveal the dominant product } \\
\text { portfolio of Danube cruise tourism. }\end{array}$ & $\begin{array}{c}\text { Online data collection about the } \\
\text { dominant suppliers (cruise } \\
\text { companies). }\end{array}$ & RQ \\
\hline $\begin{array}{c}\text { Identification of the micro-niche } \\
\text { elements of the current } \\
\text { (2019-2020-2021) product portfolio of } \\
\text { the dominant market players. }\end{array}$ & $\begin{array}{c}\text { Analysis of the dominant suppliers } \\
\text { (cruise companies)' current supply } \\
\text { with content analysis (CA). }\end{array}$ & Q1-Q2 \\
\hline $\begin{array}{c}\text { Creating proposals for product } \\
\text { development and prioritising } \\
\text { niche-elements. }\end{array}$ & & Q3 \\
\hline
\end{tabular}




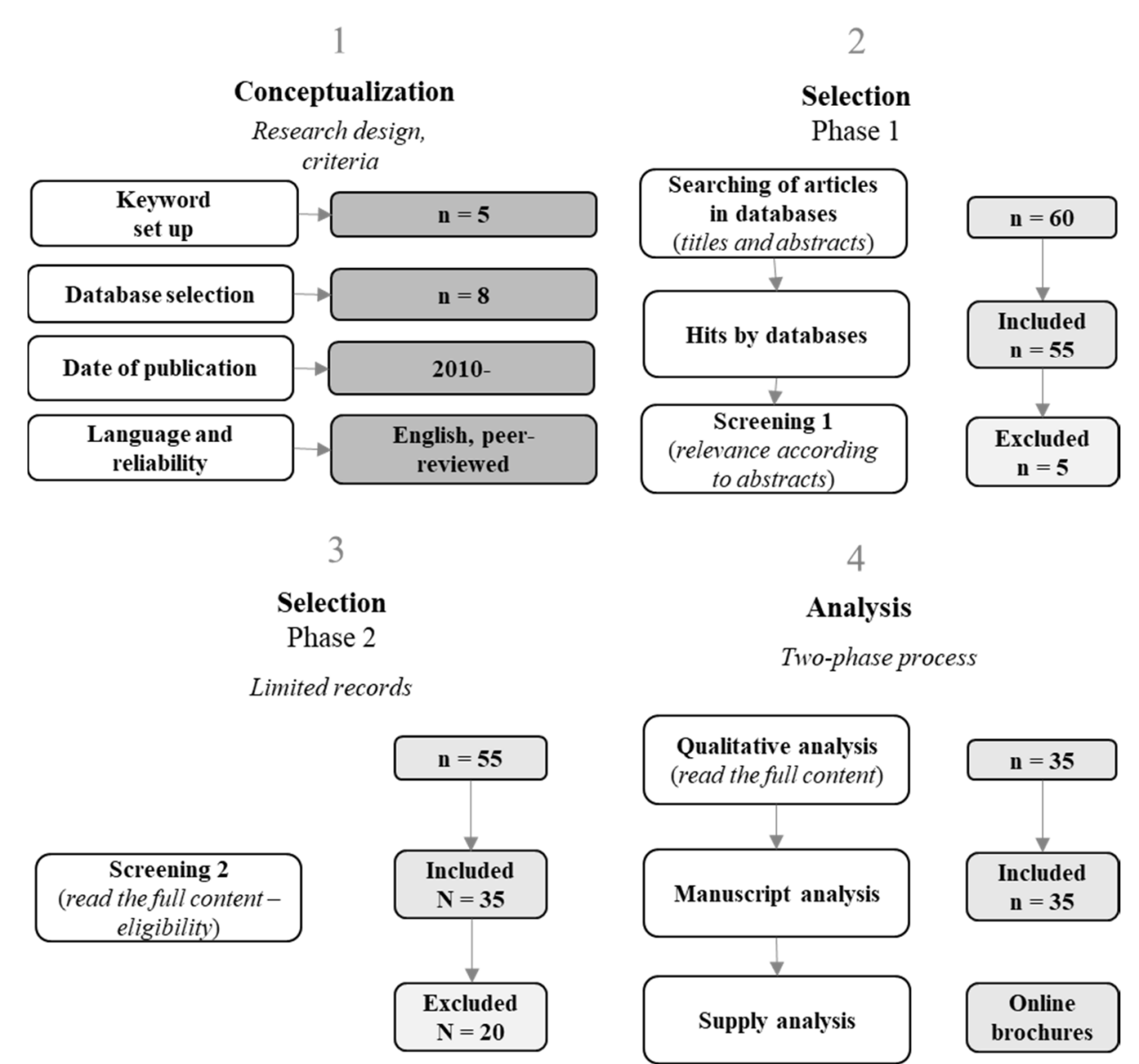

Figure 2. Research process. Source: authors' own editing.

Table 2. Keywords of the literature review. Source: authors' own editing.

\begin{tabular}{cc}
\hline Keywords & Records \\
\hline cruise industry & 14 \\
river cruise tourism & 11 \\
Danube tourism & 13 \\
Danube cruise tourism & 16 \\
River Danube tourism & 6 \\
5 & 60 \\
\hline
\end{tabular}

Table 3. Literature review on cruise tourism. Source: authors' own selection.

\begin{tabular}{|c|c|c|c|c|c|}
\hline Nr. & Author & Year & Area & Topic & Focus \\
\hline 1 & Armenski et al. & 2009 & Europe (Serbia) & Danube cruise tourism & $\begin{array}{l}\text { Role of Danube cruises in the tourism of } \\
\text { the country }\end{array}$ \\
\hline 2 & Ásványi et al. & 2015 & Europe (Hungary) & Danube cruise tourism & $\begin{array}{l}\text { Role of Danube cruises in the tourism of } \\
\text { the country }\end{array}$ \\
\hline 3 & Belij et al. & 2014 & Europe (Serbia) & Danube cruise tourism & $\begin{array}{l}\text { Role of Danube cruises in the tourism of } \\
\text { the country }\end{array}$ \\
\hline 4 & Brida-Zapata & 2010 & Europe & River cruise tourism & General introduction of river cruises \\
\hline 5 & Brida-Zapata & 2010 & Costa Rica & $\begin{array}{l}\text { Ocean-going cruise } \\
\text { tourism }\end{array}$ & $\begin{array}{l}\text { Economic analysis of the ocean-going } \\
\text { cruise industry }\end{array}$ \\
\hline 6 & Cerveny et al. & 2020 & America & $\begin{array}{l}\text { Ocean-going cruise } \\
\text { tourism }\end{array}$ & Environmental issues of the industry \\
\hline 7 & Csapo-Darabos & 2011 & Europe & Water tourism & $\begin{array}{l}\text { Introduction of different types of water } \\
\text { tourism (river and ocean-going cruises) }\end{array}$ \\
\hline
\end{tabular}


Table 3. Cont.

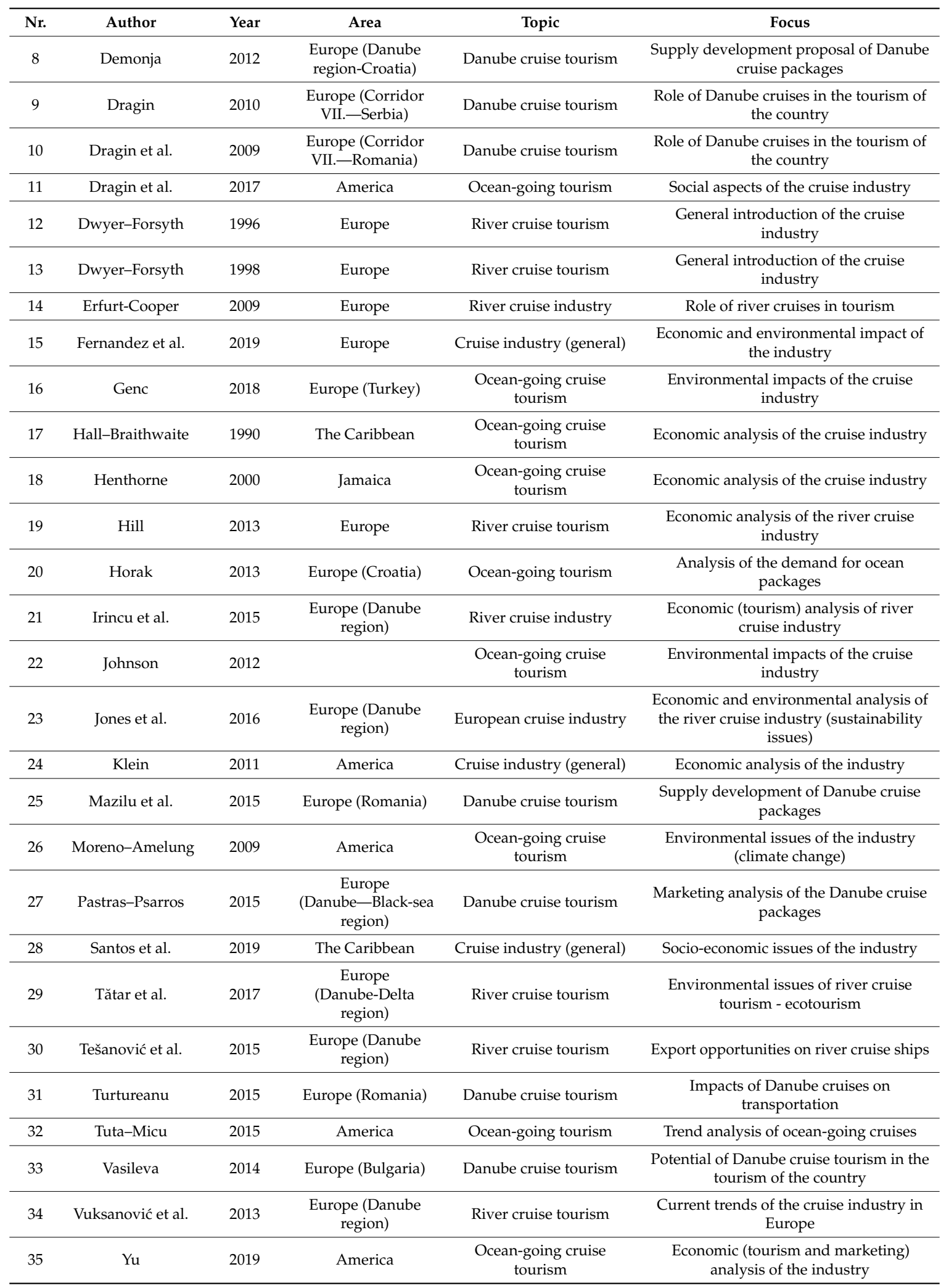

The keyword search resulted 60 related records (Table 2), and a reduction (Selection 1) was based on the title and abstract of the articles. Following this first exercise, the number of articles was reduced to 55, but, after reading the full content (Selection 2), 20 additional manuscripts were excluded from our analysis. Finally, 35 articles were analysed during the LR process (Table 3). 
The qualitative analysis was a two-stage process, which began with the analysis of the scientific articles. After this, with the identification of the dominant market role players, the current supply of the selected six cruise companies (Tauck (https://www.tauck.co.uk/), Avalon Waterways (https: //www.avalonwaterways.com/), Crystal Cruises (https://www.crystalcruises.com/), Uniworld River Cruises (https://www.uniworld.com/eu/), Viking River Cruises (https://www.vikingrivercruises.co.uk/), and Scenic River Cruises (https://www.scenic.com.au/)) were analysed with the help of content analysis.

During the research, content analysis was applied to determine which niche elements appear in the Danube cruise tourism supply and which are not included in the programmes. In content analysis, there is no direct relationship between the researcher and the observation unit [22]. The method is used for the analysis of written texts, during which we can examine the frequency of use of words and phrases used in the document examined [23]. The method is suitable for analysing any type of material (e.g., publications, guest books, articles, or visual content etc.) [24]. In this case, the key variables of operationalisation are the brochures of the six dominant cruise companies over the whole Danube for the years 2019-2020-2021, which were analysed on the basis of material published on official online websites.

The method itself is a coding process, as the information collected during the analysis is classified according to a pre-developed conceptual framework [25]. In our study, micro-niche elements appearing in travel descriptions were identified and grouped based on the niche typology. During content analysis, a manifest coding of the service providers' announcements was performed, which includes the determination of the frequency of the units (niche elements) which are the focus of our research. One of the most important advantages of content analysis is that the units of analysis are easily and quickly accessible via the internet, and consequently the application of the method is easy and economical [25].

CA1: Qualitative content analysis can be divided into three main work phases (Figure 3), the first of which is the coding process. In this phase, certain parts of the text (coding units) which are words appearing in the cruise product portfolio referring to niche programmes and attractions are identified. Only the meanings of words and sentences in the text can be coded [24].

4 Analysis - Phase 2

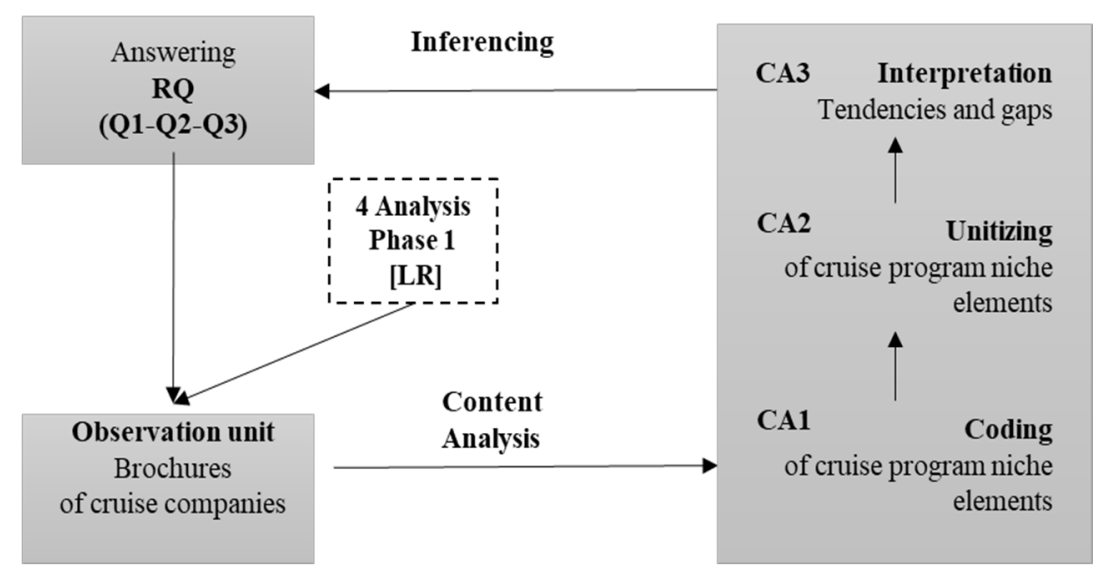

Figure 3. Content analysis process. Source: authors' own editing based on [21].

CA2: The content so encoded is then examined in the second phase with the number of appearances in a given code category being totalled. Here, also in the second stage, the concepts which are not present also come to the surface (latent content-in this case, niche elements on which the product range is not currently based $[24,26]$.

CA3: The third stage is interpretation. The tendencies to co-occurrence in the text allow regularities to be deduced-which enables interpretation [23]. If, however, a regularities document does not contain a code (a specific niche element), then this also helps us to understand the product design strategy and gaps and future development options. This is interpreted in Section 5. 


\section{Results of the Literature Review-The Emergence of Danube Cruise Tourism}

Based on our review of the literature (Table 3), research on cruise tourism has focused primarily on ocean-going cruises e.g., [27-31]. In that case, the emphasis is mainly on environmental impacts, e.g., [27,31,32], and the economic performance of the industry, e.g., [33-36], and in many cases river cruise tourism is only mentioned in passing. Some European research analyses Danube cruise tourism in more detail, e.g., [33-35], based on which we show the specifics of the industry. It is important to emphasise that data gathered from scientific articles were needed to supplement current industry reports $[1,2,37,38]$ to refine current trends and performance.

\subsection{General Introduction}

Throughout our history, shipping has been considered a tool of great importance at various levels of transportation (e.g., between continents) [28]. The transport sector first embraced tourism in the 1960s and 1970s [28]. However, by today, the continuous innovation and growth of the tourism product with its unique offers, have been able to conquer new markets. The development of the European cruise industry began in 1992 with the opening of the $171 \mathrm{~km}$ long Rhine-Main-Danube Canal [30,34,35]. Before that, the two European water systems, the Rhine and the Danube, were both geographically and physically separated by a watershed of more than $400 \mathrm{~m}$ [30]. Following the handover of the canal, the two water systems were connected, creating a 3500-km waterway from the North Sea to the Black Sea [39] (Figure 4).

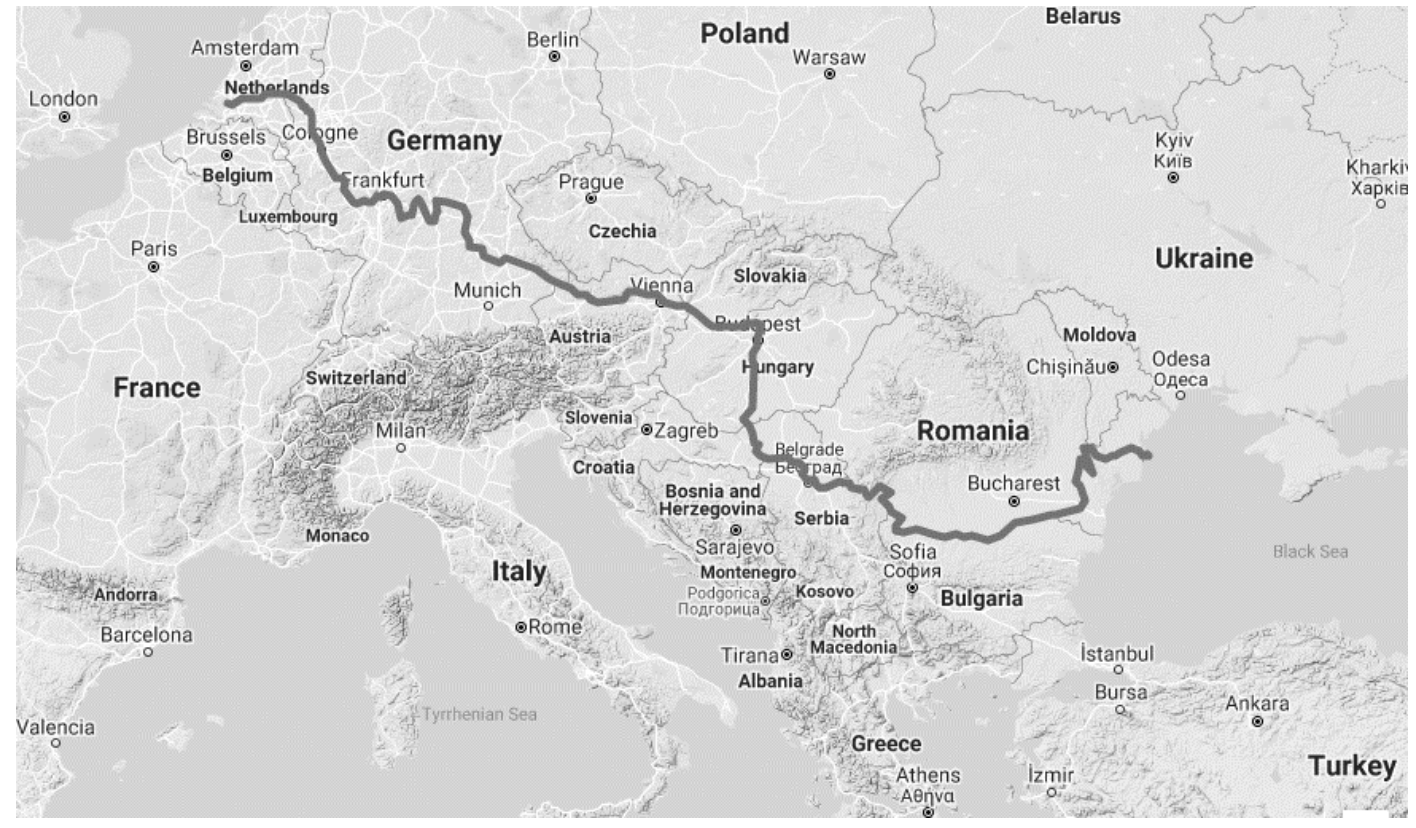

Figure 4. The 3500-km Rhine-Main-Danube waterway: Rotterdam, North Sea to Constanța, Black Sea. Source: own editing using Google My Maps.

Even though the primary goal of the canal was to develop the freight transport function, the tourism sector soon understood the economic potential of the natural resource, and already in the year following the opening, approximately 20 cruise ships were operating (mainly in the Rhine countries) $[36,40]$. These were now able to navigate the whole length of the canal [34]. The locks are $12 \mathrm{~m}$ wide [30] and a significant number of the bridges are a clear $6 \mathrm{~m}$ above water level, and so the first challenge to the sector was to adapt the design of cruise ships to the canal's infrastructure [34]. In terms of its main dimensions, the canal itself is $171 \mathrm{~km}$ long, $11.5 \mathrm{~m}$ wide, provides $6.2 \mathrm{~m}$ bridge clearance, and its depth varies between $1.7 \mathrm{~m}$ and $2.1 \mathrm{~m}$ [36]. With new uses for shipping, the physical capacity of vessels has expanded, and their equipment has also changed $[3,30,34,36,39]$. It is worth 
noting that, without the strict regulation of inland waterway navigation, this segment of the tourist industry would simply not have been feasible.

\subsection{Supply Characteristics, Basic Trends of the Cruise Industry}

In the case of cruise tourists, the accessibility of attractions differs from that experienced by "traditional" tourists visiting specific destinations [33]. The on-board services of cruise vessels can be characterised by complexity and luxury $[3,34]$ (main characteristics-Table 4). The services offered include various recreational as well as cultural features (on-board library, classical music evenings, etc.) [41]. Thematic packages, such as dancing lessons, theatre visits, gastronomic programmes play a significant role in the programme offerings [42]. River cruise vessels typically have three decks, about 100 suites, rooms with balconies, a lounge, a sun deck, and a restaurant $[43,44]$. The importance of gastronomy should also be emphasised, and passengers can often become acquainted with the traditional dishes of the destination on board [45]. An emerging, attractive development is wine tourism, on which more and more thematic products are based. Gastronomy and wine tourism can operate well with wellness products, as health-conscious eating habits (whole-meal, organic, gluten-free foods, etc.) and the moderate consumption of wine form an attractive thematic package for the primary consumer segments. In addition to a feeling of luxury, a family atmosphere also plays a significant role. Compared to ocean liners, the capacity of river cruise vessels is much lower, and the duration of voyages can be up to 15-25 days (Figure 5), which also provides an opportunity to make new acquaintances [46]. Although river vessels abound in premium quality on-board services, the range of services available is narrow compared to ocean liners. As a result, in the case of river cruise tourism more emphasis is placed on building on the attractions which can be reached along the route, and on getting to know the tourist offers of river destinations [46].

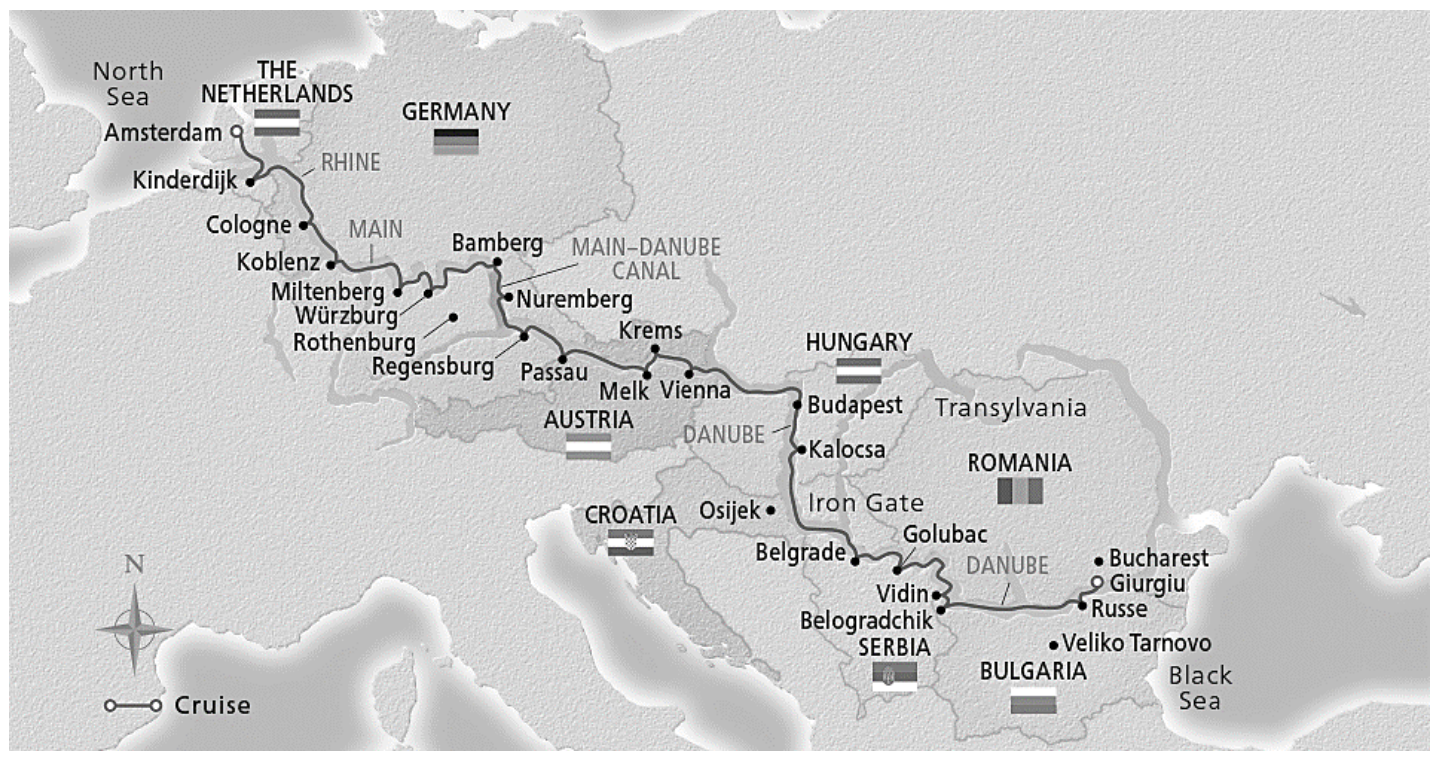

Figure 5. Danube river cruise package: An example: duration: 23 days, visited countries: 8, departure date: 2021. Source: Viking River Cruise's official website.

The product offer is also shaped by seasonality, typically 8-9 months of intensive operation are replaced by 3-4 off-season months, during which only special thematic trips (e.g., visiting Christmas fairs) are likely [27-29]. The whole season on the Danube lasts from the end of February to the beginning of January, the peak being from spring to autumn $[30,31,47]$. The starting and finishing points of the cruises are in the best position, as they have the opportunity to convince passengers to extend their stay, to get to know the destination better, and so the product can generate additional revenue for the tourist providers of the destination visited $[6,48,49]$. The reason for the growing popularity of river 
cruising is that the river environment offers not only natural beauty but also architectural attractions, and all this is accompanied by many historical and cultural experiences [50-53]. Danube cruise tourism should be considered as part of a combined trip. Most large river cruise companies also operate a stand-alone bus fleet, and these buses run parallel to the vessel [36]. This ensures that passengers can take part in optional bus programmes as soon as their vessel reaches its next destination. The market is characterised by the strengthening of competitive behaviour, Currently, 10-12 companies share the market, and we highlight the six major ones $[34,41,42,54]$.

Table 4. Basic trends of Danube cruise tourism supply. Source: authors' own collection based on LR process.

\begin{tabular}{cc}
\hline Characteristic & Description \\
\hline Type of the packages & Trips organised by travel agencies with few optional program elements \\
\hline Mobility & Flying to and from the first/last port, autobuses within and between destinations, \\
public transport (rarely)
\end{tabular}

\subsection{Characteristics of Tourists Interested in Danube Cruise Tourism}

There is a growing interest among tourists in unusual modes of transport. This can be seen if the primary motivation has become to maximise the possibilities of gaining experience (a desire to see as many destinations as possible during a given trip), and to minimise the need for relocation and means of transport use $[46,47]$. Danube cruise tourism provides a solution to the partly contradictory consumer demand, as the following form of travel allows atypical mobility preferences to be met in luxury and under safe travel conditions [48]. The economic driver of the radical growth rate is mainly the high standard of living of the population of the sending countries (e.g., Western Europe-Germany, North America, Australia and China-Figure 6) and the significant discretionary income of the consumer segment interested in the product (Table 5) [49].

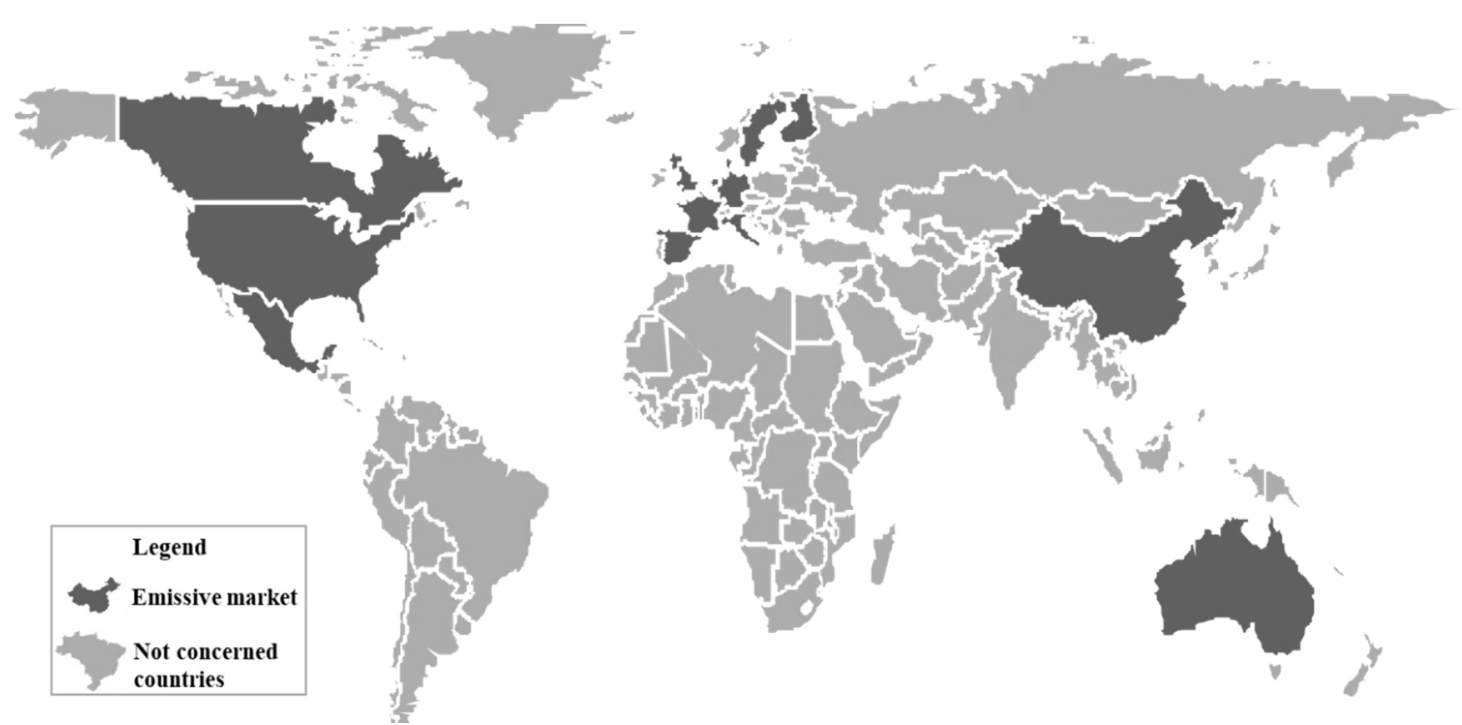

Figure 6. Top sending countries of Danube cruise tourism. Source: authors' own editing using Envato.com map templates. 
Table 5. Characteristics of the primary consumer segment. Source: authors' own collection based on literature reviews (LR) process.

\begin{tabular}{cc}
\hline Feature & Description \\
\hline Age & Seniors (65+) \\
\hline Lifecycle & Pensioners in small friend groups or married couple \\
\hline Emissive markets & Europe: German, Scandinavian, Dutch, British, Italian, \\
& French, Spanish, Danish \\
Income & High (upper middle class) \\
\hline Consumer attitude & Risk-averse, comfort-oriented \\
\hline Motivation & Authenticity, deep interest \\
\hline Mobility preferences & Accessibility, high-comfort, luxury \\
\hline
\end{tabular}

The number of tourists traveling on a Danube cruise ship reached almost half a million passengers in $2018(496,270)$ [37]. River cruise tourism has traditionally been popular among senior travellers, and the over-65 age group is still the primary target group [49,50]. Based on the age composition of tourists, the $66-75$-year-old group (41.1\%) dominates, followed by the 56-65 age segment (26.7\%) [50]. A significant proportion of tourists consciously plan a cruise vacation. A total of $32 \%$ of trips are booked by tourists 14-18 months before departure, the remaining berths usually being sold out 4-6 months before sailing [55]. Reports have revealed $[38,55]$ that tourists prefer to book voyages of more mixed composition (such as cruises on the Danube) through travel agencies to avoid any kind of omissions, their primary motivation being to seek an authentic experience [56], to immerse themselves in the adventure [57], and to explore alternative attractions [30]. Cruisers are mainly married couples or a small group of friends $[31,36]$. All providers try to create special on-board programmes in response to alternative needs (music programmes, wine tasting, on-board yoga, karaoke, and board players, etc.) [58]. In the most advanced packages, the programme offerings are now much more flexible: travellers can decide whether or not to actively explore the area and local attractions [42,59].

Based on the results of the latest CLIA (Cruise Lines International Association) survey, $57 \%$ of those surveyed say that the price-value of Danube cruise tourism is acceptable [38]. The target group is generally characterised by risk-averse behaviour and are sensitive to current political crises. They make their travel decisions carefully, depending on the news. Based on previous research $[49,50]$, due to actual crises (e.g., accidents, terrorist attacks in some parts of the world that received more attention), $10 \%$ of groups may cancel the prepaid journey. Danube cruise tourism is also able to move in a lower price range, and the programme offer complements the traditional tourist offer with alternative elements [50]. It is important to emphasise that a comfortable, safe form of transport and accessibility are of huge importance to the target group. This is because the health status (mobility-impaired, musculoskeletal problems, etc.) of the primary target group usually has specific needs [44].

\subsection{River Cruise Tourism-Economic Performance Indicators}

After the 1970s, cruise holidays were offered mostly in the Caribbean, and their popularity was boosted by the region's glorious landscapes enjoyed from the comfort of a luxury cruise-diner. This also boosted the European river cruise industry [34,60-62]. Danube cruise tourists spend an average of USD 41.2 million every year. A significant part of this expenditure $(46 \%)$ is generated by participation in optional programmes (e.g., shopping, tickets for tourism services), the rest is additional travel-related costs (e.g., transportation, taxes) [37]. It is projected [55] that by 2022 the cruise market on the Danube will grow by $6 \%$, although this figure has become uncertain due to the pandemic (COVID-19). There were 359 registered vessels in Europe last year (2019), 250 of which worked on the Rhine-Main-Danube waterway and the rest on other navigable rivers or canals [37]. 
The importance of Danube cruises is also shown by the fact that its 359 vessels account for $44 \%$ of the total river cruise traffic worldwide [38]. Surprisingly, the second largest such business area is the Nile, where more than 20 percent of the world's river cruise traffic is based [37]. On the Danube most passengers board in Vienna. Vienna has a specially constructed harbour to accommodate cruise vessels: each berth has a separate lockable garbage collector; vessels can be immediately connected to the drinking water network, the shore power network to an electricity meter, and even to the sewage network, so that already treated waste-water generated on board can be discharged into the land-based sewerage system [60]. Budapest is one of its main competitors [30]. Most cruise companies organise trips only in the middle section of the Danube, between Passau and Budapest [42]. The Danube cruise market is capable of development, but we also need to consider some of the factors that limit the volume of Danube cruises and passengers. One of the main problems is the availability of trained and experienced captains. It only takes a year to build a new vessel, but it is only possible to train captains who can safely navigate the whole river in 5-10 years of study and the same length of time of direct experience [42].

\section{Results of Content Analysis}

\subsection{Dominant Market Players-Key Characteristics of Product Portfolio}

One of the biggest Danube service providers is Tauck River Cruises, which has been successfully selling packages for more than 90 years as a family business [63]. Its services are broad, offering luxury conditions at an average price of USD 5000-6000 [63]. The service provider primarily tries to satisfy the needs of the senior segment, and the product range is dominated by elegance and cultural attractions. Founded in 2002 in collaboration with Irish, German, and Austrian owners, AmaWaterways currently operates 21 vessels [64]. In the compilation of packages and the interior design of their vessels, they strive for a friendly but premium quality, and-according to self-assessment-the strength of AmaWaterways is the diversity of the on-board gastronomic offerings. As a member of La Chaîne des Rôtisseurs (International Association of Gastronomy), they pay special attention to the quality of food. Several wine routes have been included in their offer to enhance gastronomy [64]. AMA Waterways and Avalon Waterways have also developed a variety of themed tours focusing on learning about Jewish heritage and religious sites (e.g., Prague, Vienna and Budapest) [65]. Whilst other companies follow a well-established portfolio of existing river cruises, Crystal Cruises offers services based on new award-winning ocean liners. The main differences are, for example, open restaurants, the relatively low number of guests (aiming for a less crowded deck), on-board health and fitness centres, and indoor swimming pools [66]. The suites are spacious, even the smallest is 188 square meters. European cruises are a minimum of 7-8 days, and the lowest-priced packages start at USD 3000 [66].

Uniworld Boutique River Cruise Collection operates cruise ships whose interior design is similar to that of boutique hotels. Boats, which have become popular with tourists from the USA, have uniquely designed, special but minimalist interiors, and their style features primarily attract passengers who require modern elegance. The strength of the service provider is the detail in the design of the interiors of floating boutique hotels: it provides unique, hand-made decorative elements (e.g., mirrors, stairs, antique oil paintings), trompe-l'oeil (an art technique that generates the optical illusion that the painted objects exist in three dimensions) painted ceilings, marble columns, and many other features reminiscent of luxury, combined with the latest technical equipment [67]. Australian-owned Scenic River Cruises operates elegant but lighter-style 5-star hotel-boats across Europe. The company boasts the largest suites in European river cruise tourism. It offers a wide range of luxury services, a spa area, several exclusive restaurants and a sun terrace. In respect of decoration, compared to Uniworld's vessels, it features a less classical and a fresh, more modern style [67]. Their package offers include several optional sightseeing programmes and tours from city tours to wine tasting.

The average prices of Uniworld River Cruises packages are around USD 4000-7000, with most selling 8- and 11-15-day cruises [67]. Viking River Cruises is perhaps one of the best-known providers 
cruise tourism on the Danube. With its marketing activities and high-quality services, it has become one of the dominant companies in the sector, its products being sold worldwide. The packages offered by Viking are full of historical and artistic elements (museum visits, historical monuments, etc.) [68] as well as wine tasting, traditional gastronomy, folklore, and music programmes [68]. Average prices for Viking packages range from USD 1800 to 3800, and most fare for 8-16-day trips [68].

Based on the official websites of the companies [63-68], all companies strive for environmentally conscious operation, although, they do not emphasise this in the brochures. New vessels follow waste management plans, use solar panels or other alternative sources (such as wind) that provide emission-free energy, and strive for energy-saving operation with automatic lighting and air conditioning system.

Through our review of the companies' websites, we can see that Danube cruise tourism is primarily being promoted through some form of niche tourism (special gastronomy, authenticity and cultural experience). To clarify the presence of other niche elements in Danube cruise tourism, a content analysis on the brochures is required, the results of which are discussed in the next chapter.

\subsection{Niche Elements of the Product Portfolio-The Three Sections of Content Analysis}

\subsubsection{Coding}

During the content analysis, we identified several travel packages with different themes and content (Table 6). For two companies, the brochures for 2022 were not yet uploaded at the time of the analysis. However, there are many identical elements in the product offer of the six companies examined, whilst there are significant overlaps, and a new package in only 1-1 programmes (e.g., based on different themes-Christmas market vs. Tulip season) or destination (different starting points). Hence, the numbers in Table 6 do not represent completely different travel packages. After collecting the brochures, the first phase of our content analysis (CA1) began, which involved manual collection, i.e., the simple selection of attractions which appear in brochures, followed by unitising (CA2).

Table 6. Number of different cruise packages along the Danube in the six cruise companies included by the analysis. Years: 2020-2021-2022. Source: authors' own collection based on content analysis (CA) process.

\begin{tabular}{cccc}
\hline Cruise Company. & $\mathbf{2 0 2 0}$ & $\mathbf{2 0 2 1}$ & $\mathbf{2 0 2 2}$ \\
\hline Tauck River Cruises & 15 & 15 & 0 \\
AmaWaterways & 26 & 28 & 0 \\
Crystal Cruises & 34 & 38 & 38 \\
Uniworld & 14 & 14 & 14 \\
Viking River Cruises & 6 & 7 & 5 \\
Scenic River Cruises & 24 & 24 & 24 \\
$\Sigma$ & 119 & 126 & 81 \\
\hline
\end{tabular}

\subsubsection{Unitising}

In the second step of the content analysis (CA2), the attractions collected in the first phase were categorised according to the niche typology, which helped to identify the dominant niche elements and the gaps (missing elements) of the product portfolio. Although the analysis is qualitative, Table 7 associated with Figure 7 shows the proportion of identified attractions-which sheds light on the dominant niche groups. 
Table 7. Frequency of appearance of some niche elements based on content analysis (CA2). Source: authors' own collection based on CA process.

\begin{tabular}{|c|c|c|}
\hline Niche Group & $\mathbf{Q}$ & $\%$ \\
\hline Cultural & 2608 & $87.92 \%$ \\
\hline Heritage tourism & 1251 & $42.17 \%$ \\
\hline Tribal & 27 & $0.91 \%$ \\
\hline Religious & 568 & $19.15 \%$ \\
\hline Educational & 305 & $10.28 \%$ \\
\hline Genealogy & 457 & $15.40 \%$ \\
\hline Research & 0 & $0 \%$ \\
\hline Environmental & 95 & $3.20 \%$ \\
\hline Nature and wildlife & 0 & $0 \%$ \\
\hline Ecotourism & 0 & $0 \%$ \\
\hline Adventure & 0 & $0 \%$ \\
\hline Alpine & 0 & $0 \%$ \\
\hline Geotourism & 95 & $3.20 \%$ \\
\hline Coastal & 0 & $0 \%$ \\
\hline Rural & 156 & $5 \%$ \\
\hline Farms & 0 & $0 \%$ \\
\hline Wine and gastronomy & 73 & $2.46 \%$ \\
\hline Sport & 0 & $0 \%$ \\
\hline Festival and events & 25 & $0.84 \%$ \\
\hline Arts and crafts & 58 & $1.95 \%$ \\
\hline Transhumance & 0 & $0 \%$ \\
\hline Urban & 107 & $3.60 \%$ \\
\hline Business & 0 & $0 \%$ \\
\hline Conference & 0 & $0 \%$ \\
\hline Exhibition & 66 & $2.22 \%$ \\
\hline Sport & 0 & $0 \%$ \\
\hline Gallery and art & 0 & $0 \%$ \\
\hline Medical & 41 & $1.38 \%$ \\
\hline Emerging & & \\
\hline Photographic & 0 & $0 \%$ \\
\hline Small cruise & 0 & $0 \%$ \\
\hline Volunteer & 0 & $0 \%$ \\
\hline Dark & 0 & $0 \%$ \\
\hline Youth & 0 & $0 \%$ \\
\hline Sex & 0 & $0 \%$ \\
\hline Space & 0 & $0 \%$ \\
\hline$\Sigma$ & 2966 & $100 \%$ \\
\hline
\end{tabular}

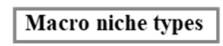

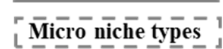

TOURISM TRENDS

\begin{tabular}{|c|c|c|c|c|}
\hline & $\begin{array}{c}\text { MASS TOURISM } \\
\text { Conventional tourism market } \\
\text { where a large mumber of people } \\
\text { appears }\end{array}$ & $\begin{array}{l}\text { NICHE TC } \\
\text { Special tourism } \\
\text { small mumber of }\end{array}$ & $\begin{array}{l}\text { RISM } \\
\text { arket where a } \\
\text { eople appears }\end{array}$ & \\
\hline CUltural & ENVIRONMENTAL & RURAL & URBAN & EMERGING \\
\hline $\begin{array}{l}\text { Heritage tourism } \\
\text { Tribal } \\
\text { Religious } \\
\text { Educational } \\
\text { Genealogy } \\
\text { Research }\end{array}$ & $\begin{array}{l}\text { Nature and wildlife } \\
\text { Ecotourism } \\
\text { Adventure } \\
\text { Alpine } \\
\text { Geotourism } \\
\text { Coastal }\end{array}$ & $\begin{array}{l}\text { Farms } \\
\text { Wine and gastronomy } \\
\text { Sport } \\
\text { Festival and events } \\
\text { Arts and crafts } \\
\text { Transhumance }\end{array}$ & $\begin{array}{l}\text { Business } \\
\text { Conference } \\
\text { Exhibition } \\
\text { Sport } \\
\text { Gallery and Art } \\
\text { Medical }\end{array}$ & $\begin{array}{l}\text { Photographic } \\
\text { Small cruises } \\
\text { Volunteer } \\
\text { Youth } \\
\text { Sex } \\
\text { Space }\end{array}$ \\
\hline
\end{tabular}

Figure 7. Micro-niche elements of Danube cruise tourism—results of content analysis. Source: authors' own editing based on [10] (with modifications). 
The CA2 process, i.e., the weighting of niche categories based on the frequency of appearance of attractions shows, that most of the cultural niche category dominate the product range, including heritage tourism, religious, and educational (e.g., museums) micro-niche elements (Table 7). It is important to emphasise that the numbers in the table do not indicate specific attractions, but the frequency of appearance of a particular type of attraction (e.g., church). We can see that, in addition to the cultural niche, rural, urban tourism and, to a very limited extent, the environmental niche group also appear in the offer. In the case of rural tourism, wine and gastronomy are particularly important (e.g., wine tasting, visits to wine regions, traditional food tasting, visits to high-quality restaurants, on-board restaurant offerings), which may be accompanied by various festivals and events. In 2020, for example, AmaWaterways will offer more than 60 themed wine tours across Europe [65]. Authentic supply is an important part of Danube cruise tourism, which is made possible by admiring and purchasing handicraft products (e.g., Grassalkovich Castle in Gödölló (Hungary)—buying products related to the Sissi cult and other Hungaricums) [30]. In the case of urban tourism, the importance of exhibitions should also be noted, which usually appears in connection with the products listed above.

Even though the primary target group of medical tourism is the senior age group, the significance of medical tourism (e.g., spas, various medical treatments,) is extremely small in Danube cruise tourism. Emerging niche elements (e.g., photographic, volunteer, youth) do not appear in the offer at all.

\subsubsection{Interpretation}

As the cultural niche is a key part of the product offering according to the frequency of appearance of the attractions, we also categorised each micro-niche of the cultural niche group (Table 8). The table also shows some of the more important attraction types and examples.

The attractions and museums with different historical pasts into the research category could also be classified, but, in this case, tourists do not visit these attractions for research purposes, and so these attractions were listed with the other micro-niche groups. The table shows the frequency of appearance of each cultural niche element and their proportion within the cultural niche group and within all niche categories. Among the elements of the cultural niche, the role of castles and royal buildings is the most significant. In addition, the organisers rely heavily on the built heritage, which represents the uniqueness of a given destination when designing the offer (e.g., special points in the city). In addition to heritage tourism, the role of religion is notable; the different religious buildings, religious monuments, and historical events define the themes of many journeys. The different cultures and folk customs also appeared in the supply, as well as the role of educational institutions (e.g., museums) and attractions (e.g., theatres, birthplaces of famous people,). The role of attractions of the urban, environmental, and emerging niche categories is negligible. 
Table 8. Cultural micro-niche typology—elements and examples for destinations and attractions. Source: authors' own selection based on CA process.

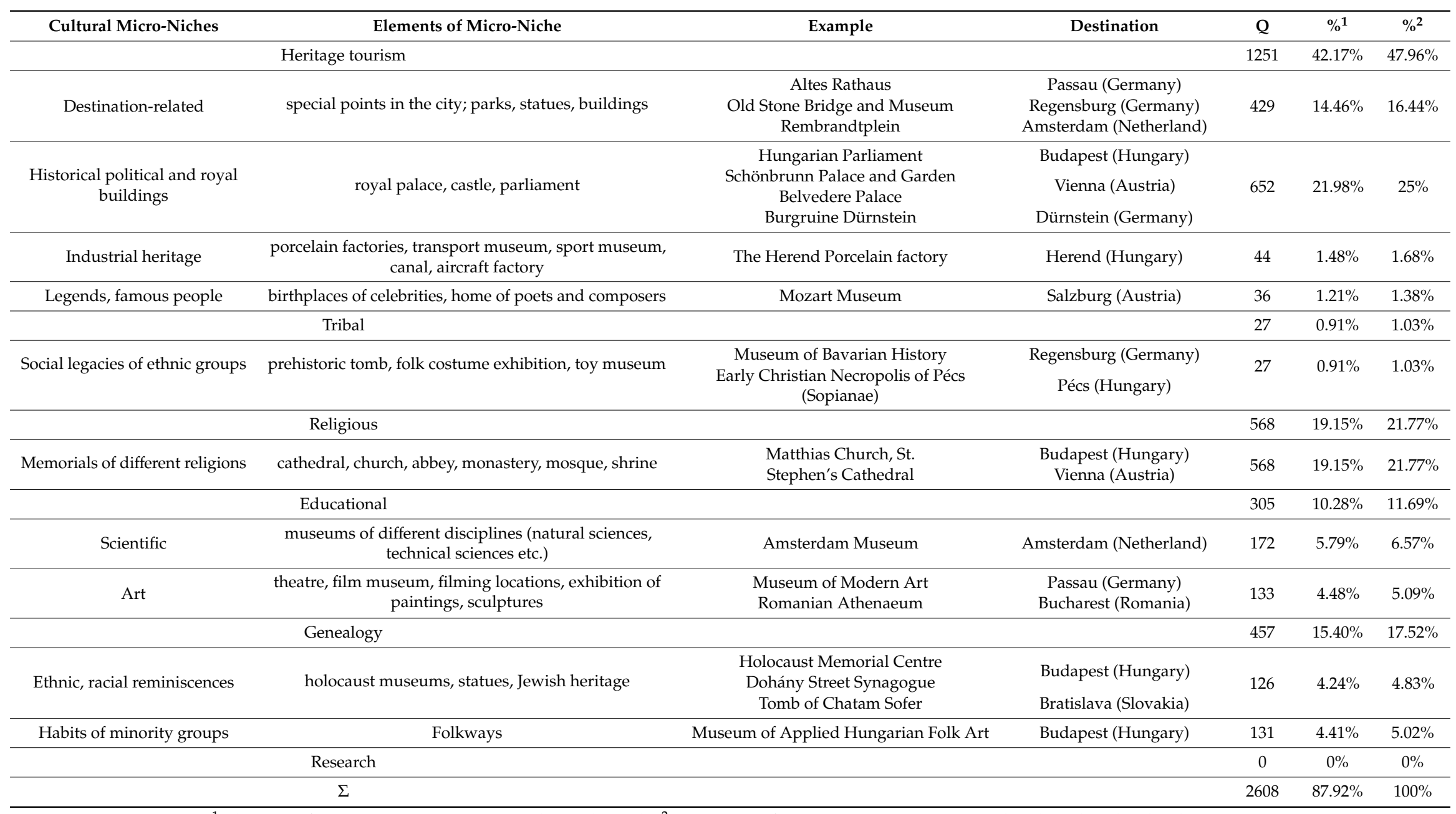

${ }^{1}$ The ratio of a certain attraction group to the total supply. ${ }^{2}$ Proportion of a certain attraction group within the cultural niche elements. 


\section{Research Outcomes}

One of the most important scientific contributions of the study is that the results facilitate a deeper classification of Danube cruise tourism as a tourism product, as also within niche typology, which were missing from the current literature. For a clearer definition, the literature review of articles dealing with the cruise industry in general and especially with Danube cruise tourism and the content analysis of the brochures were necessary. The LR process showed that Danube river cruise tourism, unlike ocean-cruise tourism, is not a segment of mass tourism for three reasons. Firstly, the supply characteristics showed that the dual function of the vessel (as an attraction and a means of transport, and its design (luxury and special onboard services)) distinguishes the product from traditional mass tourism offers (1) (e.g., round trips by bus, recreational holidays etc.). It offers only physically tight space together with slow travel and provides alternative visual stimuli (panorama from the river not available in any other form of tourism. Furthermore, the supply and demand characteristics proved, that, unlike ocean-going cruise ships, Danube cruise tourism focuses on a narrow segment, which is attracted by a special range of products which primarily build on authenticity (2). In addition to the homogeneity of the segment, the price range and duration of the voyages also differ from traditional tourism trips. Further, the results of our content analysis (especially the unitising process (CA2)) show, that Danube cruise tourism combines niche elements of destinations visited (3), in which cultural micro-niche elements $(87.92 \%)$ dominate. Overall, we can define Danube cruise tourism as a hybrid niche product which combines cultural micro-niche elements (heritage, tribal, religious, educational, genealogical), partially including rural niche (wine and gastronomy, festival and events, arts and crafts) and urban niche (exhibition, medical) experience offerings.

However, the results also point to some concerns. Through the unitising process of CA, we can see that the current supply of Danube cruise tourism is quite extensive, it relies primarily on cultural (mainly on heritage and religious) micro-niche elements, which narrows the target group to the senior sector. Further, the unitising process revealed the gaps of the current product construction, i.e., the omission of various niche products. With the current supply, the risks of niche tourism (e.g., unexpectedly declining demand due to the sensitivity of the narrow segment) are difficult to manage, especially in the current situation. There is a chance that the economic performance of Danube cruises declines, given that the primary target group is exposed to the COVID-19 pandemic, resulting in cancellations and few new bookings. The six leading companies did not embark on a major transformation of the product range, as the economic indicators did not require this, but changes can be introduced which increase the stability of the industry in the longer term. Based on our results, we can say that meeting the needs of the current target group with new niche elements, as well as involving new target groups, should be continued. This can be addressed in several ways:

\subsection{Experience Diversification along with the Current Niche Elements}

For the primary segment, the importance of the currently dominant cultural niche elements will remain in the long run, but previous research proves $[11,30,69]$ that tourists will require more and more visual stimuli and special experiences in general. This can be achieved in Danube cruise tourism by creative product development: the telling of legends and stories has already appeared strongly in the offers (e.g., the cult of Empress Sisi), but it is worth expanding. "Storytelling" can also use personal involvement: for example, the proximity of local people ("be the guest of a local family") or the performance and experience of traditional activities ("do it yourself", e.g., a traditional lunch and drinks) can be successful, according to the preferences of the primary target group.

\subsection{Increasing Operations in the Lower Section of the Danube and Other Niche Elements for the Core Segment}

It is also important to consider the capacity of the destinations visited. In addition to inadequate product management, Danube cruise tourism can generate overtourism and so reduce the accessibility of attractions and weakening the sustainability of the product. Overtourism can become common 
in institutions (especially museums) and in the case of historical city centres, main squares, but can be mitigated by incorporating more niche elements into the product offering. An example of this is medical tourism. Currently, medical tourism is neglected in Danube cruise tourism, despite the fact that the senior age group is its primary target group $[70,71]$ and it could strengthen the alternative nature of the product. Many European cities offer high-quality medical services. For example, due to the thin crust of the Earth, the geothermal gradient of Hungary (the increase in temperature per unit of increase in depth) is much higher than the world average and in some spots reaches up to $58.9^{\circ} \mathrm{C}$ [72]. The result is that the country abounds in thermal baths. It would also be worthwhile to involve more the destinations of the southern section of the Danube between Budapest and the Black Sea in the offer. The offering of the middle and lower Danube sections could meet the needs of the current target group, even if only this section is concerned by the packages. The articles from the region proved $[35,42,47]$ that these countries abounds in authenticity, many historical, political, royal buildings and memorials of different religions (e.g., Belgrade (Bulgaria): St. Sava Temple, St. Michael's Cathedral, Crkva Svetog Marka, Residence of Princess Ljubica; Vidin (Bulgaria): Vidin Synagogue, Krastata Kazarma; Baba Vida Fortress) could be visited.

\subsection{Targeting New Consumer Groups and Markets}

The current challenge for river cruise tourism is to involve the younger generation as well as families. The socio-cultural trend in which individualist attitudes dominate [37] seems to be increasing among consumers (especially in Western society). In response, it may be also necessary to design single cabins and acquire specialised programs for singles based on the example of ocean liners-cruises for solo travellers [37]. Tourists from Asia are an emerging segment, and future product development, must understand and satisfy their interest and preferences. This global inclusion strategy can be a success factor for niche tourism as well as a creator of sustainable tourism.

\subsection{Image Extension-Nature and Entertainment}

With the current product portfolio, cruises currently offer limited opportunities to enjoy close-to-nature experiences, despite the fact that the basic concept of the product is based on natural resources (the Danube and the panorama seen from the vessel). Utilising the natural environment of the Danube for tourism purposes can be an adequate way to attract the younger segment. This is supported by the growing environmental awareness of the $\mathrm{Y}$ and $\mathrm{Z}$ generations [73,74], the desire to preserve nature. This requires the development of the ecotourism image of Danube cruise tourism (e.g., possibilities of exploring the biodiversity along the Danube, endeavour active experiences (e.g., cruising, hiking, canoeing, kayaking, cycling), put more emphasis on the environmentally-conscious efforts of ships in marketing activities), i.e., strengthening the environmental niche in the portfolio. In addition to (or linked to) the thematic product design, it may be worthwhile (for all segments) to encourage participation in festivals. Based on the content analysis, the festivals are mainly presented only as an optional program, even though the need for active and local experience is gaining an increasing role among cruise tourists.

\section{Conclusions}

In our research, the basic characteristics of Danube cruise tourism, the current supply (2020-2022) were shown and the potential of niche tourism was highlighted with the review of 35 articles. In the second phase of the research, which was a content analysis, all types of attraction which have appeared in the supply of the biggest six companies were identified and grouped.

The results pointed to the possible shortcomings of the product, on the basis of which we answered our research questions (Table 9) and formulated our proposals. Product portfolio development would be an important tool to minimise the impacts of a potential economic crisis in the post-epidemic period (in the second half of 2020 and early 2021). Overall, we can say that product development based on niche elements can support a better distribution of tourists in the destinations, by which we can ensure 
that Danube cruise tourism does not add to the impacts of overtourism, and more alternative (niche) attractions could benefit from the river cruise industry. Based on the analysis, this study can serve as a basis for further research on niche tourism and as a guide for the development of the product portfolio.

Table 9. Summary of the results and answering of research questions (RQs). Source: Authors' own collection based on the results of LR and CA.

\begin{tabular}{|c|c|c|c|}
\hline Code & Research Q & Answer & Result \\
\hline RQ & $\begin{array}{l}\text { What micro-niche elements does Danube } \\
\text { cruise tourism embrace? }\end{array}$ & $\begin{array}{l}\text { Danube cruise tourism is a special hybrid of cultural, rural } \\
\text { and urban niche elements. }\end{array}$ & \multirow{2}{*}{ CA } \\
\hline Q1 & $\begin{array}{l}\text { Which micro-niche element dominates the } \\
\text { product range and why? }\end{array}$ & $\begin{array}{c}\text { Cultural micro-niches: heritage tourism }(42.17 \%) \text {; tribal } \\
(0.91 \%) \text {; religious }(19.15 \%) \text {; educational }(10.28 \%) \text {; genealogy } \\
(15.40 \%) .\end{array}$ & \\
\hline \multirow{3}{*}{ Q2 } & \multirow{3}{*}{$\begin{array}{l}\text { What other micro-niche elements could be } \\
\text { incorporated into the offering for successful } \\
\text { product development and to alleviate the } \\
\text { impacts of the recession? }\end{array}$} & Urban niche (medical tourism and sport micro niche) & \multirow{7}{*}{ LR and CA } \\
\hline & & $\begin{array}{c}\text { Environmental niche (nature and wildlife, ecotourism micro } \\
\text { niches) }\end{array}$ & \\
\hline & & Rural niche (festival and events, sport micro niche) & \\
\hline \multirow{4}{*}{ Q3 } & \multirow{4}{*}{$\begin{array}{l}\text { What kind of gaps can be identified in } \\
\text { product development, and what additional } \\
\text { market research directions are appropriate? }\end{array}$} & Lack of intensive experience diversification & \\
\hline & & $\begin{array}{l}\text { Neglect of new consumer groups (especially of generation } \mathrm{Y} \\
\text { (Millennials) and Z) and other niche elements }\end{array}$ & \\
\hline & & Disregard of the lower section of the Danube & \\
\hline & & $\begin{array}{l}\text { Lack of communication about the emerging environmental } \\
\text { conscious operation }\end{array}$ & \\
\hline
\end{tabular}

\section{Limitations}

It is important to emphasise that in the course of the analysis we analysed the current offerings (2020-2022) of the six most significant service providers, and so the research results only reflect the perspective of these companies. Some of the programs for 2022 may still undergo significant changes, given the current situation, which could change the credibility of our results. An extension of research perspectives could also cover the offerings of smaller companies, which may include several specific niche elements.

Further research could be specified by analysing the demand (tourists), in which the focus could be on exploring the factors, which influence consumer decisions. In the case of consumer surveys, it is important to reveal the needs of different age groups (seniors, generation $Y$, and $Z$ ) and their intention to participate in Danube cruise tourism and interest in different types of niche tourism in order to support and expand our suggestions presented in this study. This could also help to clarify the importance of niche elements in cruise packages, so helping companies to develop a more successful product development concept.

Author Contributions: Each author has contributed substantially to conducting the research and drafting this manuscript. All authors have read and agreed to the published version of the manuscript.

Funding: This research received no external funding.

Conflicts of Interest: The authors declare no conflict of interest.

\section{References}

1. Cruise Lines International Association. Cruise Industry Outlook; Cruise Lines International Association: Washington, DC, USA, 2018.

2. Danube International Programme. Cruise Tourism in the Danube Region. Final Report; Ministry of Tourism of the Republic of Bulgaria: Sofia, Bulgaria, 2019.

3. Johnson, D. Environmentally sustainable cruise tourism: A reality check. Mar. Policy 2002, 26, 261-270. [CrossRef]

4. Brida, J.G.; Zapata, S. Cruises tourism: Economic, socio-cultural and environmental impacts. International J. Leis. Tour. Mark. 2010, 1, 205-226. [CrossRef] 
5. Moreno, A.; Amelung, B. Climate change and coastal \& marine tourism: Review and analysis. J. Coast. Res. 2009, 2, 1140-1144.

6. Cerveny, L.K.; Miller, A.; Gende, S. Sustainable cruise tourism in marine world heritage sites. Sustainability 2020, 12, 611. [CrossRef]

7. Rátz, T.; Michalkó, G.; Keszeg, R. Educational tourism and nation building: Cross-border school trips in the Carpathian Basin. Hung. Geogr. Bull. 2020, 69, 57-71.

8. Knowles, T.; Curtis, S. The market viability of european mass tourist destinations: A Post-stagnation life-cycle analysis. Int. J. Tour. Res. 1999, 1, 87-96. [CrossRef]

9. Smith, S.L. The tourism product. Ann. Tour. Res. 1994, 21, 582-595. [CrossRef]

10. Novelli, M. (Ed.) Niche Tourism: Contemporary Issues, Trends and Cases; Elsevier Butterworth-Heinemann: Oxford, UK, 2005.

11. Marson, D. From mass tourism to niche tourism. In Research Themes for Tourism; Robinson, P., Heitmann, S., Dieke, P.U., Eds.; CABI: Cambridge, MA, USA, 2011; pp. 1-11.

12. Ali-Knight, J. The Role of Niche Tourism Products in Destination Development. Ph.D. Thesis, Edinburgh Napier University, Edinburgh, UK, 2010.

13. Dinis, A.; Krakover, S. Niche tourism in small peripheral towns: The case of Jewish heritage in Belmonte, Portugal. Tour. Plan. Dev. 2016, 13, 310-332. [CrossRef]

14. Nordin, S. Tourism Clustering \& Innovation: Paths to Economic Growth E Development; Etour: Tokyo, Japan, 2003.

15. Wilhelm Stanis, S.A.; Barbieri, C. Niche tourism attributes scale: A case of storm chasing. Curr. Issues Tour. 2013, 16, 495-500. [CrossRef]

16. Hall, C.M.; Weiler, B. (Eds) Special Interest Tourism; Belhaven Press: London, UK, 1992.

17. Cooper, C. Tourism: Principles and Practice; Pearson education: London, UK, 2008.

18. Jennings, G. Water-based tourism, sport, leisure, and recreation experiences. In Water-based Tourism, Sport, Leisure, and Recreation Experiences; Routledge: Thames, UK, 2007; pp. 19-38.

19. Holloway, J.C.; Humphreys, C. The Business of Tourism; SAGE Publications Limited: Thousand Oaks, CA, USA, 2019.

20. Denney, A.S.; Tewksbury, R. How to write a literature review. J. Crim. Justice Educ. 2013, 24, $218-234$. [CrossRef]

21. Avni, A.; Burley, P.; Casey, P.; Cherney, J.; Christiansen, L.; Daly, J.S.; Rita, E.; David, J.; Greg, L.; Andrew, M.; et al. Literature searches and literature reviews for transportation research projects. How to search, where to search, and how to put it all together: Current practices. Transp. Res. Circ. 2015, 13, E-C194.

22. Wee, B.V.; Banister, D. How to write a literature review paper? Transp. Rev. 2016, 36, 278-288. [CrossRef]

23. Malhotra, N.; Hall, J.; Shaw, M.; Oppenheim, P. Marketing Research: An Applied Orientation; Pearson Education Australia: Melbourne, Australia, 2006.

24. Krippendorff, K. Validity in Content Analysis; University of Pennsylvania: Philadelphia, PA, USA, 1980.

25. Babbie, E.R. The Practice of Social Research; Nelson Education: Toronto, ON, Canada, 2015.

26. Hsieh, H.F.; Shannon, S.E. Three approaches to qualitative content analysis. Qual. Health Res. 2005, 15, 1277-1288. [CrossRef] [PubMed]

27. Genc, Ruhet. Environmental sustainability and the future of the cruise tourism. Çukurova Üniversitesi İktisadi ve İdari Bilimler Fakültesi Derg. 2018, 22, 107-114.

28. Hall, J.A.; Braithwaite, R. Caribbean cruise tourism. Tour. Manag. 1990, 11, 339-347. [CrossRef]

29. Henthorne, T.L. An analysis of expenditures by cruise ship passengers in Jamaica. J. Travel Res. 2000, 38, 246-250. [CrossRef]

30. Jászberényi, M.; Ásványi, K. The image of Budapest as the best river cruise port city. Metrop. Tour. Exp. Dev. 2015, 11, 140-148.

31. Vuksanović, N.; Pivac, T.; Dragin, A. Contemporary trends in nautical tourism on the example of European river cruising companies. Res. Rev. Dep. Geogr. Tour. Hotel Manag. 2013, 42, 122-138.

32. Klein, R.A. Responsible cruise tourism issues of cruise tourism and sustainability. J. Hosp. Tour. Manag. 2011, 18, 107-118. [CrossRef]

33. Armenski, T.; Zakić, L.; Dragin, A.S. The perception of foreign tourists on the image of Serbia. Glas. Srp. Geogr. Drus. 2009, 89, 39-63. [CrossRef]

34. Belij, S.; Ilinčić, M.; Belij, J.; Belij, M. Sustainable planning and tourism development policy exemplified by medieval fortresses along the river Danube. Glas. Srp. Geogr. Drus. 2014, 94, 69-82. [CrossRef] 
35. Dragin, A.S.; Jovicic, D.; Lukic, T. Cruising along the river Danube-Contemporary tourism trend in Serbia. Geogr. Pannonica 2010, 14, 98-108. [CrossRef]

36. Dragin, A.; Bubalo-Živkovic, M.; Ivanović, L.J. The Romanians on international cruises along the Corridor VII: The structure of the crew on tourist boats. Geogr. Timisiensis 2009, 1-2, 35-44.

37. Cruise Industry News. 2020 Annual Report; Cruise Industry News: New York, NY, USA, 2020.

38. Cruise Lines International Association. Cruise Trends and Industry Outlook; Cruise Lines International Association: Washington, DC, USA, 2019.

39. Csapó, J.; Darabos, F. Vízi közlekedés. In Turizmus és közlekedés; Veres, L., Ed.; Pécsi Tudományegyetem, Kempelen Far-kas Hallgatói Információs Központ: Page, Hungary, 2011.

40. Demonja, D. The importance of the Danube strategy for tourism and culture development of the Croatian Danube region. Geogr. Pannonica 2012, 16, 112-125. [CrossRef]

41. Horak, S. Demand for nautical tourism in Europe-case study Croatia. In Nautical Tourism; Lukovic, T., Ed.; University of Dubrovnik: Dubrovnik, Croatia, 2013.

42. Turtureanu, A.G. The current state of tourism traffic along the danube on the romanian territory. Acta Univ. Danub. OEconomica 2015, 11, 141-148.

43. Dwyer, L.; Forsyth, P. Economic impacts of cruise tourism. J. Tour. Stud. 1996, 7, 36-43.

44. Dwyer, L.; Forsyth, P. Economic significance of cruise tourism. Ann. Tour. Res. 1998, 25, 393-415. [CrossRef]

45. Mazilu, M.; Limbert, W.; Mitroi, S.R. Opportunity for Romania according to the danube strategy: Cruise tourism. J. Tour. Chall. Trends 2005, 8, 79.

46. Gabe, T.M.; Lynch, C.P.; McConnon, J.C. Likelihood of cruise ship passengers return to a visited port: The case of Bar Harbor, Maine. J. Travel Res. 2006, 44, 281-287. [CrossRef]

47. Jones, P.; Comfort, D.; Hillier, D. European river cruising and sustainability. Int. J. Sales Retail. Mark. 2016, $5,61-71$.

48. Fernández Gámez, M.A.; Sánchez Serrano, J.R.; Callejón Gil, A.; Cisneros Ruiz, A.J. Cruise passengers' intention and sustainable management of cruise destinations. Sustainability 2019, 11, 1929. [CrossRef]

49. Santos, M.; Radicchi, E.; Zagnoli, P. Port's role as a determinant of cruise destination socio-economic sustainability. Sustainability 2019, 11, 4542. [CrossRef]

50. Yu, J. Verification of the Role of the Experiential Value of Luxury Cruises in Terms of Price Premium. Sustainability 2019, 11, 3219. [CrossRef]

51. Page, S.J.; Connell, J. Tourism: A Modern Synthesis; Routledge: London, UK, 2020.

52. Holloway, J.C. Marketing for Tourism; Pearson education: London, UK, 2004.

53. Dragin, A.; Dragin, V.; Košić, K.; Demirović, D.; Ivkov-Džigurski, A. Tourists motives and residents attitude towards cruisers. South. East. Eur. 2017, 4, 133-144.

54. Tuta, L.; Micu, C. The cruise tourism-A megatrend of the international tourism. Lucr. Manag. Agric. 2015, 17,1 .

55. Cruise Lines International Association. Cruise Travel Report. 2018. Available online: https://cruising.org/ docs/default-source/research/clia-2018-consumer-research.pdf (accessed on 10 April 2020).

56. Tešanović, D.; Vuksanović, N.; Kalenjuk, B.; Portić, M. Tourist ships on the Danube as an opportunity for export of meat and meat products. Econ. Agric. 2015, 62, 527-542.

57. Irincu, E.; Petrea, R.; Racz, N.; Filimon, L. Cruise ship tourism on the Danube river. Case study: Capitalization of Deltaic tourism potential. Ann. Univ. Oradea Geogr. Ser. 2015, 2, 276-286.

58. Tătar, C.F.; Herman, G.V.; Dehoorne, O.; Zarrilli, L. Ecotourism in the Danube Delta. An. Univ. din Oradea Ser. Geogr. 2017, 27, 122-132.

59. Vasileva, V. In the Danube Tourist Region of Bulgaria. Geogr. Tour. 2014, 2, 51-59.

60. Xu, S.; Barbieri, C.; Seekamp, E. Social capital along wine trails: Spilling the wine to residents? Sustainability 2020, 12, 1592. [CrossRef]

61. Erfurt-Cooper, P. European waterways as a source of leisure and recreation. River Tour. 2009, 3, 95-116.

62. Pastras, P.; Psarros, M. Challenges for interregional place branding for cruise tourism in the Black Sea Region. In Inter-Regional Place Branding; Springer: Cham, Switzerland, 2015; pp. 139-160.

63. Tauck River Cruises. Danube River Cruises. 2020. Available online: https://www.tauck.co.uk/tours-andcruises/european-river-cruises/danube-river (accessed on 14 April 2020).

64. Ama Waterways. Europe Cruises. 2020. Available online: https:/www.amawaterways.com/destination/ europe-river-cruises/2020/romantic-danube (accessed on 14 April 2020). 
65. Avalon Waterways. Danube River Cruises. 2020. Available online: https://www.avalonwaterways.com/rivercruises/danube-river/ (accessed on 14 April 2020).

66. Crystal Cruises. Danube River Cruises. 2020. Available online: https://www.crystalcruises.com/voyagefinder?regions $=\%$ C2\%A0-\%20Danube\%20River++danr (accessed on 14 April 2020).

67. Uniworld. River Cruises. 2020. Available online: https://www.uniworld.com/eu/river-cruise/?selectedRiver= 26001FB4A4E045D1B6176C4C5DF13958 (accessed on 14 April 2020).

68. Viking River Cruises. 2020. Available online: https://www.vikingrivercruises.co.uk/cruise-destinations/ europe/rivers/danube/index.html?YearMonthKey=2020-12 (accessed on 14 April 2020).

69. Hanna, P.; Font, X.; Scarles, C.; Weeden, C.; Harrison, C. Tourist destination marketing: From sustainability myopia to memorable experiences. J. Destin. Mark. Manag. 2018, 9, 36-43. [CrossRef]

70. Zsarnoczky, M.; David, L.; Mukayev, Z.; Baiburiev, R. Silver tourism in the European Union. GeoJ. Tour. Geosites 2016, 18, 224-232.

71. Ikinci, S.S. A rising value: Health tourism. In Recent Studies Health Sciences; Chernopolski, P.M., Shapekova, N.L., Sancar, B., Bilal, A.K., Eds.; ST. Kliment Ohridski University Press: Sofia, Bulgaria, 2019; pp. 696-703.

72. Toth, A.N. Creating a geothermal atlas of Hungary. Nat. Gas 2017, 424, 380-386.

73. Özkan, P.M. Generation Z-the global market's new consumers-and their consumption habits: Generation Z consumption scale. Eur. J. Multidiscip. Stud. 2017, 2, 150-157. [CrossRef]

74. Fayos-Sol, E.; Cooper, C. The Future of Tourism; Springer International Publishing: Cham, Switzerland, 2019.

(C) 2020 by the authors. Licensee MDPI, Basel, Switzerland. This article is an open access article distributed under the terms and conditions of the Creative Commons Attribution (CC BY) license (http://creativecommons.org/licenses/by/4.0/). 